\title{
Poly-Silicon Passivating Contacts for Silicon Solar Cells: Interface Passivation and Carrier Transport Mechanism
}

Wenzhu Liu,,${ }^{1,+}$, Xinbo Yang,,${ }^{1,}$ Jingxuan Kang,,${ }^{1,+}$ Shuai Li, ${ }^{1}$ Lujia Xu, ${ }^{1}$ Song Zhang,,${ }^{2}$ Hang Xu, ${ }^{1}$ Jun Peng, ${ }^{3}$ Feng Xie, ${ }^{4}$ Jui-Han Fu, ${ }^{5}$ Kai Wang, ${ }^{1}$ Jiang Liu, ${ }^{1}$ Areej Alzahrani, ${ }^{1}$ Stefaan De Wolf ${ }^{1,},{ }^{*}$

${ }^{1}$ King Abdullah University of Science and Technology (KAUST), KAUST Solar Center (KSC), Thuwal 23955-6900, Saudi Arabia

${ }^{2}$ Shanghai Shenzhou New Energy Development Co., Ltd, Shanghai 201112, China

${ }^{3}$ Research School of Engineering, the Australian National University, Canberra, ACT 2601, Australia

${ }^{4}$ Advanced Membranes and Porous Materials Center, Physical Science and Engineering Division, King Abdullah University of Science and Technology, Thuwal 23955-6900, Saudi Arabia

${ }^{5}$ Physical Science and Engineering Division, King Abdullah University of Science and Technology, Thuwal 23955-6900, Saudi Arabia

ABSTRACT: Poly-silicon passivating contacts, consisting of a stack of tunnel-oxide and doped poly-silicon layers, can simultaneously provide excellent surface passivation and low contact resistivity for silicon solar cells. Nevertheless, the microscopic interfacial characteristics of such contacts are not yet fully understood. In this work, by investigating the surface passivation evolution of poly-silicon passivating contacts under increasing annealing temperatures, we unveil these characteristics. Before annealing, we find that the $\mathrm{Si}$ and $\mathrm{O}$ atoms within the tunneloxide layer are mostly unsaturated, whereas the $\mathrm{O}$ atoms introduce acceptor-like defects. These defects cause Fermi-level pinning and high carrier recombination. During annealing, we identify two distinct chemical passivation regimes driven by surface hydrogenation and oxidation. We attribute the excellent chemical passivation activated by high-temperature annealing $\left(\sim 850^{\circ} \mathrm{C}\right)$ mainly to the tunnel oxide reconstruction, which effectively reduces the acceptor-like state density. During the oxide reconstruction, we also find that sub-nanometer pits (rather than pinholes) are formed in the oxide. A combination of experimental and theoretical investigations demonstrates these sub-nanometer pits provide excellent surface passivation and efficient tunneling for majority carriers.

KEYWORDS: silicon solar cell, tunnel oxide passivating contacts, sub-nanometer pits, pinholes, unpin Fermi level 


\section{INTRODUCTION}

Crystalline silicon ( $c-\mathrm{Si}$ ) wafer-based photovoltaics (PV) technology accounted for $\sim 95 \%$ of the total commercial production in 2018. ${ }^{1-2}$ To further improve the competitiveness of photovoltaics with conventional energy sources, it is essential to increase the power conversion efficiency (PCE) of $c$-Si solar cells. In this context, recent years have witnessed the gradual transition of the dominant silicon-PV production technology from the traditional aluminum back surface field (Al-BSF) cell to passivated emitter and rear cell (PERC) designs, resulting now in production PCEs over 20\%. ${ }^{3}$ However, PERC cells feature localized metal-silicon contacts which increases the process complexity; moreover, these localized contacts still suffer from high recombination.

To push forward the practical PCE of silicon solar cells, the passivating contact concept was developed to minimize the recombination loss at the contact areas. ${ }^{4-5}$ There is a widespread consensus that the next generation $c$-Si PV production will be based on advanced passivatingcontact technology. To date, the passivating-contact technologies can be divided into three different types: silicon heterojunction technology (SHJ), ${ }^{6-14}$ 'dopant-free' passivating contacts (DFPCs), ${ }^{15-20}$ and poly-crystalline silicon (or poly-Si) based passivating contacts, consisting of doped poly-Si layers on thin $\mathrm{SiO}_{x}$ layers. We label these here as poly-Si/SiO$x$ stacks, but they are also sometimes referred to as TOPCon (tunnel-oxide passivating contacts) or POLO (poly-Si on oxide) contacts. ${ }^{21-24} \mathrm{SHJ}$ contacts, which consist of a stack of intrinsic and doped hydrogenated amorphous silicon $(a-\mathrm{Si}: \mathrm{H})$, offer excellent surface passivation; the world-record efficiency of $26.7 \%$ has been achieved by applying SHJ contacts in an interdigitated back-contact design. ${ }^{6}$ However, SHJ technology shows a moderate thermal resilience $\left(<250^{\circ} \mathrm{C}\right)$, relatively narrow process windows, and a capital-intensive deposition system is required as well. ${ }^{25-26}$ With a conventional both-side contact design, the SHJ device suffers from parasitic absorption of $a$-Si:H, which limits the short-circuit current density, $J_{\mathrm{SC}}{ }^{27}$ This has been the main motivation to develop so-called 'dopant-free' passivating contacts, using more transparent contacting materials. By implementing metal-oxide (e.g., $\mathrm{TiO}_{2}, \mathrm{MoO}_{x}$ ) based DFPCs, silicon solar cells with PCE over $22 \%$ have been achieved. ${ }^{15-16}$ Although those DFPCs may be fabricated with low-cost methods, they often suffer either from poor surface passivation or thermal stability issues. In contrast, poly$\mathrm{Si} / \mathrm{SiO}_{x}$ passivating contacts exhibit a very good thermal tolerance, but also a very high efficiency potential, on par with SHJ technology. An efficiency of $25.8 \%$ has been achieved by 
implementing a full-area poly-silicon rear contact. ${ }^{23}$ Moreover, such contacts may be integrated in a relatively straight-forward way into current $c$-Si PV production lines as hole-selective passivating rear contacts, replacing PERC-type contact structures.

As already stated, poly-Si/SiO $x$ passivating contacts usually consist of a stack of tunnel silicon oxide $\left(\mathrm{SiO}_{x}\right)$ and doped poly-Si layers. High temperature annealing in $\mathrm{N}_{2}$ atmosphere $\left(800^{\circ} \mathrm{C}-900^{\circ} \mathrm{C}\right)$ followed by a hydrogenation step is usually required to achieve excellent surface passivation (expressed by a very low carrier recombination parameter, $J_{0}$ ) and a low contact resistivity $\left(\rho_{\mathrm{c}}\right)$ simultaneously. ${ }^{21}$ It is widely accepted that the excellent surface passivation of such contact structures must be attributed to the combined effects of chemical passivation by the tunnel oxide and field-effect passivation from the doped poly-Si. ${ }^{23-24,28-29}$ However, the microscopic structural evolution during annealing of the interfacial oxide layer, which enables simultaneously such good surface passivation and effective carrier transport is still not fully understood. Regarding the carrier transport in such contacts, either carrier tunnelling through the ultrathin oxide layer or localized carrier transport through pinholes or coexistence of both has been proposed. ${ }^{29-37}$ In this work, we unveil the interface passivation and carrier transport mechanism of the poly-Si/SiO $x$ passivating contacts by investigating the tunnel-oxide structure evolution under different annealing temperatures, using a series of characterization methods combined with numerical simulations.

\section{EXPERIMENTAL PROCEDURES}

2.1. Poly-Si passivating contacts deposition. Double-side polished $n$-type (100) oriented float-zone $c$-Si wafers $(1-5 \Omega \cdot \mathrm{cm}$; thickness: $300 \pm 25 \mu \mathrm{m})$ are cleaned by the standard RCA (Radio Corporation of America) process, followed by dipping in 2\% HF to remove oxides. The wafers are immediately moved into boiling nitric acid $\left(68 \mathrm{wt} \% \mathrm{HNO}_{3} ; \sim 120^{\circ} \mathrm{C}\right)$ for 15 min to grow tunnel-oxide layers. All wet-chemical processes are conducted in a cleanroom $(50 \%$

humidity; $22^{\circ} \mathrm{C}$ ), minimizing surface contaminations. The grown oxide layer thickness is $\sim 1.5$ $\mathrm{nm}$, determined by spectroscopic ellipsometry (SE; J.A.Woollam M2000). The doped silicon layers are deposited on both wafer sides either by plasma-enhanced chemical vapor deposition (PECVD) at $200^{\circ} \mathrm{C}$ or low-pressure chemical vapor deposition (LPCVD) at $650^{\circ} \mathrm{C}$ using a mixture of precursor gases, consisting of $\mathrm{B}_{2} \mathrm{H}_{6} / \mathrm{SiH}_{4}=5 \%$ and $\mathrm{PH}_{3} / \mathrm{SiH}_{4}=1.5 \%$, for $p$-type and 
$n$-type films, poly-Si(p) and poly-Si(n), respectively. The thickness of these doped silicon films are $\sim 30 \mathrm{~nm}$ and $\sim 50 \mathrm{~nm}$ for PECVD and LPCVD, respectively. Finally, the contact stacks are annealed in a tube furnace from $200^{\circ} \mathrm{C}$ to $950^{\circ} \mathrm{C}$ for $30 \mathrm{~min}$ with a $\mathrm{N}_{2}$ flow. Samples annealed at > $400^{\circ} \mathrm{C}$ are followed by an additional forming gas $\left(4 \% \mathrm{H}_{2}\right.$ in $\left.\mathrm{N}_{2}\right)$ annealing at $400^{\circ} \mathrm{C}$ for 30 min. As a reference, symmetric poly-Si $(n) / c-\mathrm{Si} / \operatorname{poly}-\mathrm{Si}(n)$ structures are also fabricated, in which $\mathrm{SiO}_{x}$ tunnel layers are absent. To avoid surface oxidation caused by moisture, all samples are put into the furnace at room temperature, followed by a temperature increase with $10^{\circ} \mathrm{C} / \mathrm{min}$.

2.2. Characterization. The effective carrier lifetime $\left(\tau_{\mathrm{eff}}\right)$ of the structures is measured by the quasi-steady-state photoconductance (QSSPC) method using Sinton WCT-120 instrument, usually evaluated at an injection level of $1.0 \times 10^{15} \mathrm{~cm}^{-3}$, unless stated otherwise. Fouriertransform infrared spectroscopy (FTIR) spectra are measured in the range of $750 \mathrm{~cm}^{-1}-2250 \mathrm{~cm}^{-1}$ to probe the $\mathrm{Si}-\mathrm{H}$ and $\mathrm{Si}-\mathrm{O}$ bonding environments. In each FTIR measurement, a base FZ silicon wafer is dipped in $2 \% \mathrm{HF}$ solution for $2 \mathrm{~min}$ and then is scanned using the background mode. The Si-O and $\mathrm{Si}-\mathrm{H}$ vibration signals are analyzed as an indicator of structure relaxation. To interpret the FTIR resonance frequency shift of $\mathrm{Si}-\mathrm{O}$ unit, density functional theory (DFT) calculation based predictions of the $\mathrm{Si}_{-} \mathrm{O}_{x}(x=1-4)$ IR spectra are conducted using PerdewBurke-Ernzerhof (PBE) pseudopotential in Materials Studio 2017R2. ${ }^{38}$ The software package, cutoff energy and k-point sampling are CASTEP, $500 \mathrm{eV}$ and $2 \times 2 \times 2$, respectively. Moreover, symmetric $\mathrm{SiO}_{x} / c-\mathrm{Si} / \mathrm{SiO}_{x}$ structures (prepared at identical conditions as before) are also annealed at different temperatures in $\mathrm{N}_{2}$ flow, followed by FTIR measurements. Cross-section images of poly-silicon $/ \mathrm{SiO}_{x} / \mathrm{c}-\mathrm{Si} / \mathrm{SiO}_{x} /$ poly-silicon samples annealed at $800^{\circ} \mathrm{C}$ and $900^{\circ} \mathrm{C}$ are probed by high-resolution transmission electron microscopy (HR-TEM; FEI Titan 80-300 electron microscope), in order to detect microstructural evolution in the $\mathrm{SiO}_{x}$ tunnel layer. We also measure the electron current flow at surface of the sample annealed at $850^{\circ} \mathrm{C}$ with conductive atomic force microscope (c-AFM), at a bias voltage of $500 \mathrm{mV}$. The c-AFM measurements are realized by Dimension Icon (Veeco, USA), using tip (PFTUNA, Bruker, USA) with nominal spring constant at $0.4 \mathrm{~N} / \mathrm{m}$. The biases applied on the samples were $500 \mathrm{mV}$ for $500 \times 500 \mathrm{~nm}^{2}$ scan area. The samples are first briefly dipped in $1 \% \mathrm{HF}$ solution for one minute to remove surface oxide, and then are quickly measured in the Ar protection. There exists weak light illuminated onto the samples during measurements from the observation window. Contact 
resistivity of poly-Si/SiO ${ }_{x} / c-\mathrm{Si}$ samples annealed at $800^{\circ} \mathrm{C}$ and $850^{\circ} \mathrm{C}$ are measured using the Cox and Strack method. ${ }^{39}$

2.3. Device simulation. $n$-type $c$-Si solar cells, featuring a diffused front $p^{+}$hole collector and a rear poly- $\mathrm{Si}(n) / \mathrm{SiO}_{x}$ contact for electron collection are numerically simulated using AFORSHET, integrated with a carrier-tunnel model. ${ }^{40}$ Specifically, the solar cell performance as function of the pinhole density $\left(D_{\mathrm{ph}}\right)$ and interface state density $\left(D_{\mathrm{it}}\right)$ of the tunnel-oxide layer is simulated. For this, the $\mathrm{SiO}_{x}$ layer is represented by a $1.5 \mathrm{~nm}$ membrane, whose electron affinity, band gap, and dielectric constant are chosen to be $0.9 \mathrm{eV}, 8.9 \mathrm{eV}$, and 3.9, respectively. To simulate surface defects, a layer of $1 \mathrm{~nm}$ c-Si film is assumed, featuring acceptor-like defects locating at $E-E_{\mathrm{i}}=0.18 \mathrm{eV}$, with a narrow Gaussian distribution. $D_{\mathrm{ph}}$ and $D_{\text {it }}$ are swept from $10^{-4}$ to $10^{-1}$ and from $10^{9}$ to $10^{13} \mathrm{~cm}^{-2}$, respectively. Other parameters adopted in the device simulations are displayed in Supporting Information Table S1.

\section{RESULTS AND DISCUSSION}

3.1. Surface Passivation of Poly-Si passivating contacts. Figure 1a and $1 \mathrm{~b}$ sketch the symmetric poly- $\mathrm{Si} / \mathrm{SiO}_{x}$ passivating contact structures, before and after annealing. Generally, doped $a$-Si:H layers deposited by PECVD contain a high hydrogen concentration of $\sim 10^{20}-10^{22}$ $\mathrm{cm}^{-3} \cdot{ }^{41-42}$ Most of these hydrogen atoms (>99\%) are present in the form of $\mathrm{Si}-\mathrm{H}$ bonds in the disordered bulk of the film and at the internal surfaces of voids. Some of them can also be left as $\mathrm{H}_{2}$ molecules in large voids. ${ }^{43-45}$ In this scenario, the mass density of $a$-Si:H is slightly lower than that of pure $a$-Si films. Under increasingly higher temperature $\left(>300^{\circ} \mathrm{C}\right)$ annealing, hydrogen present on internal voids recombines and effuse out. ${ }^{46}$ At even higher temperatures, also the hydrogen present in the bulk of the amorphous matrix effuse out, explaining the typical presence of two hydrogen effusion peaks when $a$-Si:H films are annealed at increasingly high temperatures. Upon such effusion, the $a$-Si matrix tends to relax into large poly-Si grains. ${ }^{47}$

Figure 1c shows the $\tau_{\text {eff }}$ of $n$-type $c$-Si substrate passivated by both poly-Si( $\left.p\right) / \mathrm{SiO}_{x}$ and poly$\mathrm{Si}(n) / \mathrm{SiO}_{x}$ contacts as a function of annealing temperature. All $\tau_{\text {eff }}$ measurements are conducted after the forming gas annealing. Phosphorus-doped $a-\mathrm{Si}: \mathrm{H}$ films are deposited by both PECVD and LPCVD, whereas boron-doped $a-\mathrm{Si}: \mathrm{H}$ films are only deposited by PECVD. All samples 
featuring either poly- $\mathrm{Si}(p) / \mathrm{SiO}_{x}$ or poly- $\mathrm{Si}(n) / \mathrm{SiO}_{x}$ layer stacks, show very low initial $\tau_{\text {eff }}(\sim 3 \mu \mathrm{s})$ at $200^{\circ} \mathrm{C}$, which indicates that before annealing the (poor) chemical passivation by $\mathrm{SiO}_{x}$ dictates the interface and passivation quality. It is obvious that the samples in this work featuring poly$\mathrm{Si}(n) / \mathrm{SiO}_{x}$ layer stacks show substantially higher $\tau_{\text {eff }}$ than that of poly-Si $(p) / \mathrm{SiO}_{x}$ contact stacks when annealed at different temperatures. This might be caused by a lower doping efficiency ${ }^{48}$ (inferred from photoconductivity data) of B atoms in the poly-Si bulk or - more likely indicates that boron penetration into the $\mathrm{SiO}_{x}$ tunneling layer increases the passivation degradation. ${ }^{49}$ Notably, two $\tau_{\text {eff }}$ peaks are observed for both poly-Si $(n) / \mathrm{SiO}_{x}$ and poly- $\mathrm{Si}(p) / \mathrm{SiO}_{x}$ contact stacks, and it is interesting that the peaks are reached at almost the same annealing temperature $\left(\sim 400^{\circ} \mathrm{C}\right.$ and $\left.\sim 850^{\circ} \mathrm{C}\right)$, independent on the $a$-Si:H dopant type or deposition method. Notably, the second peak near $\sim 850^{\circ} \mathrm{C}$ is not observed on samples without tunnel oxide (green circle). In the annealing temperature range of $200-600^{\circ} \mathrm{C}$, the $\tau_{\mathrm{eff}}$ reaches the first peak at $\sim 400^{\circ} \mathrm{C}$, followed by a decrease to a local minimum at $\sim 600^{\circ} \mathrm{C}$. Further increasing the annealing temperature results in a sharp $\tau_{\text {eff }}$ enhancement, and the second peak is reached at $\sim 850^{\circ} \mathrm{C}$ followed by a rapid decrease for higher annealing temperatures. These results suggest there must be two different passivation mechanisms at work in the annealing temperature window discussed here. 


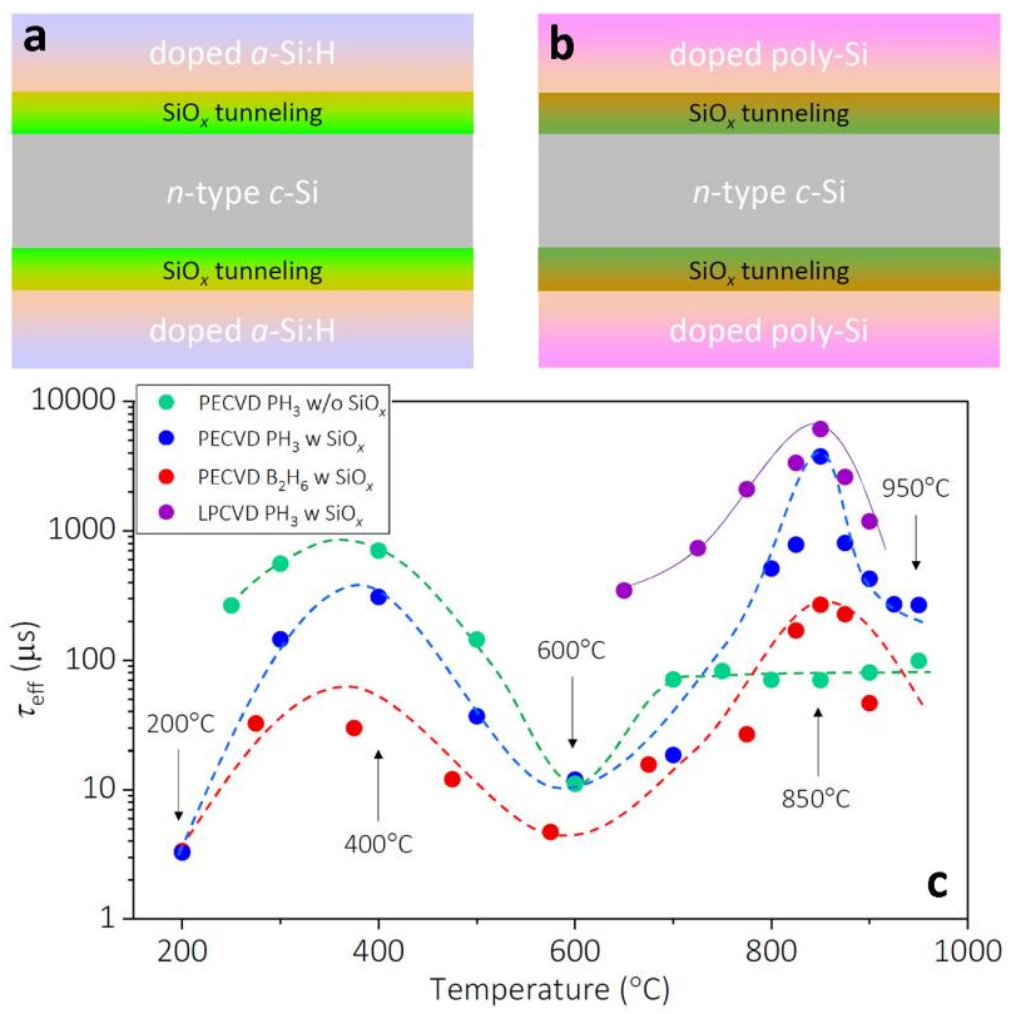

Figure 1. (a) Schematic of symmetric poly-Si/ $\mathrm{SiO}_{x}$ passivating contact structures (a) before and (b) after annealing. (c) Dependence of $\tau_{\text {eff }}$ of the samples passivated by poly-Si $(n) / \mathrm{SiO}_{x}$ and poly-Si $(p) / \mathrm{SiO}_{x}$ passivating contact structures on annealing temperature. All samples annealed at $>400^{\circ} \mathrm{C}$ underwent a forming gas $\left(4 \% \mathrm{H}_{2}\right.$ in $\left.\mathrm{N}_{2}\right)$ annealing at $400^{\circ} \mathrm{C}$ for $30 \mathrm{~min}$. All data are mean values.

\subsection{Microstructural Evolution of $\mathrm{SiO}_{x}$ Tunnel Layer. Figure 2a shows FTIR} transmittance spectra of poly- $\mathrm{Si}(n) / \mathrm{SiO}_{x}$ contact stacks annealed at different temperatures. At annealing temperatures $<600^{\circ} \mathrm{C}$, four H-related absorption signatures can clearly be observed, positioned at $845 \mathrm{~cm}^{-1}\left(\mathrm{SiH}_{3}\right.$ bending mode; see Supporting Information Figures S1-S3), 890 $\mathrm{cm}^{-1}$ ( $\mathrm{SiH}_{2}$ bending mode; see Supporting Information Figures S1-S2, and Figures S4-S5), 2000 $\mathrm{cm}^{-1}$ (bulk SiH stretching mode) and $2080 \mathrm{~cm}^{-1}$ (void SiH and $\mathrm{SiH}_{2}$ stretching modes). ${ }^{50-51}$ As the annealing temperature increases from $200^{\circ} \mathrm{C}$ to $400^{\circ} \mathrm{C}$, all H-related absorption peak intensities substantially decrease. During such annealing, two dynamic processes may occur: $a-\mathrm{Si}: \mathrm{H}$ network relaxation and hydrogen diffusion. ${ }^{52}$ In contrast, the $\mathrm{SiO}_{x}$ absorption intensity at 1040 $\mathrm{cm}^{-1}$ increases significantly from $200^{\circ} \mathrm{C}$ to $400^{\circ} \mathrm{C}$. Considering that the samples are annealed in $\mathrm{N}_{2}$ flow, the increase in $\mathrm{SiO}_{x}$ absorption intensity may indicate that a large portion of $\mathrm{O}$ atoms are reconstructed, forming $\mathrm{Si}-\mathrm{O}$ bonds. Noting that the structure without $\mathrm{SiO}_{x}$ tunnel layers also 
displays an $\tau_{\text {eff }}$ peak at $\sim 400^{\circ} \mathrm{C}$, we conclude that the $\tau_{\text {eff }}$ maxima at $400^{\circ} \mathrm{C}$ in Figure $1 \mathrm{c}$ can likely be mainly attributed to $\mathrm{SiO}_{x}$ reconstruction in the presence of $\mathrm{H}$ passivation. Ongoing study to elucidate how $\mathrm{H}$ mobility affects $\mathrm{SiO}_{x}$ reconstruction is indispensable in the future. Further increasing the annealing temperature to $600^{\circ} \mathrm{C}$ results in an on-going intensity increase of the $\mathrm{SiO}_{x}$ IR absorption peak, which suggests a further decrease of the interface defect density. However, the four H-related IR absorption peaks disappear at $600^{\circ} \mathrm{C}$ (Figure 2a), which indicates that $\mathrm{H}$ effuses away during this process, a phenomenon known to be detrimental in SHJ passivating contact stacks. Overall, the inferior $\mathrm{H}$ passivation results in the first passivation valley at $600^{\circ} \mathrm{C}$. Remarkably, at higher temperatures, the $\mathrm{SiO}_{x}$ interface passivation seems to fully compensate the absence of any hydrogenation. As an example, we find the sample has almost the same $\tau_{\text {eff }}$ values after $850^{\circ} \mathrm{C}$ annealing, no matter whether forming gas annealing at $400^{\circ} \mathrm{C}$ for $30 \mathrm{~min}$ is applied or not, after deposition. However, when the annealing temperature is increased to $>850^{\circ} \mathrm{C}$, a decrease in $\mathrm{SiO}_{x}$ absorption intensity is observed, likely explaining the loss in chemical passivation at these temperatures. This decrease in $\mathrm{SiO}_{x}$ IR absorption intensity might be caused by high temperature reaction of $\mathrm{Si}+\mathrm{SiO}_{2} \rightarrow \mathrm{SiO}$ (gas) or $\mathrm{SiO}_{x}$ reconstruction. ${ }^{21}$ 

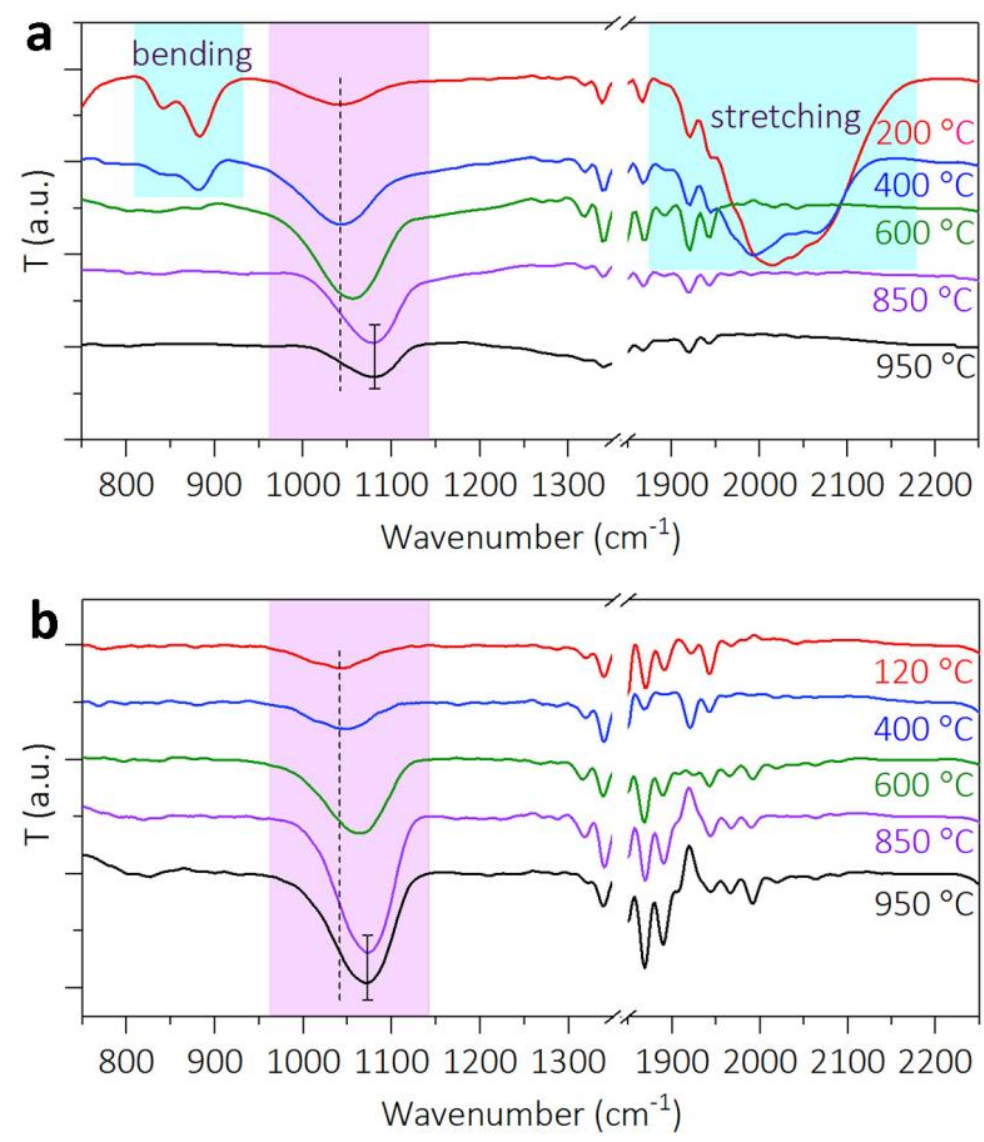

Figure 2. (a) FTIR transmittance spectra of poly- $\mathrm{Si}(n) / \mathrm{SiO}_{x}$ passivating contact structures annealed at $200^{\circ} \mathrm{C}$, $400^{\circ} \mathrm{C}, 600^{\circ} \mathrm{C}, 850^{\circ} \mathrm{C}$, and $950^{\circ} \mathrm{C}$ respectively. The a-Si:H films of these samples are deposited in PECVD chamber. Absorption at $1900-2200 \mathrm{~cm}^{-1}$ corresponds to $\mathrm{Si}-\mathrm{H}_{x}(x=1,2,3)$ stretching mode; while the two peaks at $845 \mathrm{~cm}^{-1}$ and $890 \mathrm{~cm}^{-1}$ originate from $\mathrm{Si}-\mathrm{H}_{3}$ and $\mathrm{Si}-\mathrm{H}_{2}$ bending mode respectively. (b) FTIR transmittance spectra of $\mathrm{SiO}_{x} / \mathrm{c}^{-}$ $\mathrm{Si}(n) / \mathrm{SiO}_{x}$ symmetric structures (without poly-Si( $n$ ) overlayers) annealed at different temperatures.

In Figure 2a, we also observe an obvious frequency blue shift of the $\mathrm{SiO}_{x} \mathrm{IR}$ absorption peak with increasing annealing temperature. The lower IR vibrational frequency indicates the asformed $\mathrm{SiO}_{x}$ is under-stoichiometric. ${ }^{53-54}$ To verify whether this shift is not caused by $\mathrm{Si}-\mathrm{O}$ bonds in the $a-\mathrm{Si}: \mathrm{H}$ or poly-Si overlayer, $\mathrm{SiO}_{x} / c-\mathrm{Si} / \mathrm{SiO}_{x}$ structures are annealed at similar temperatures. The corresponding FTIR transmittance spectra are shown in Figure 2b, in which the same frequency shifts are well reproduced. To exclude post-oxidation in $\mathrm{N}_{2}$ annealing process, we checked the $\mathrm{SiO}_{x}$ thickness before and after the annealing by using ellipsometry. The nominal thickness is $1.55 \mathrm{~nm}$ and $1.53 \mathrm{~nm}$ respectively, indicating the thickness of the $\mathrm{SiO}_{x}$ tunneling layer scarcely changes before $850^{\circ} \mathrm{C}$. Theoretically, this frequency blue shift can be attributed to saturation of $\mathrm{SiO}_{x}$ (i.e. due to increasing $x$ ) ${ }^{53-54}$ Figure 3a depicts four typical $\mathrm{Si}-\mathrm{O}_{x}$ 
$(x=1,2,3,4)$ atomic structures, embedded in a $\mathrm{SiO}_{2}$ network. These $\mathrm{Si}-\mathrm{O}_{x}$ models are built based on quartz $\mathrm{SiO}_{2}$, which are relaxed by DFT dynamics using GGA-PBE exchangecorrelation pseudopotential. DFT calculations predict four typical IR absorption spectra, shown in Figure 3b, whose mole ratios of $\left[\mathrm{Si}-\mathrm{O}_{4}\right]:\left[\mathrm{Si}-\mathrm{O}_{3}\right]:\left[\mathrm{Si}-\mathrm{O}_{2}\right]:[\mathrm{Si}-\mathrm{O}]$ are 4:3:0:1, 5:2:1:0, 6:2:0:0, and 8:0:0:0, where $\mathrm{Si}-\mathrm{O}, \mathrm{Si}-\mathrm{O}_{2}, \mathrm{Si}-\mathrm{O}_{3}$ and $\mathrm{Si}-\mathrm{O}_{4}$ represent characteristic structures respectively. An apparent blue shift of the $\mathrm{SiO}_{x}$ IR spectrum with increasing $x$ is found. For comparison, experimental Si-O IR absorption frequencies (vertical lines) from Figure 2a are shown as well. Their positions clearly suggest that as-deposited $\mathrm{SiO}_{x}$ has a large amount of $\mathrm{Si}$ atoms with only three neighboring $\mathrm{O}$ atoms $\left(\mathrm{Si}-\mathrm{O}_{3}\right)$. Annealing makes the under-stoichiometric $\mathrm{O}$ atoms gradually bond to adjacent $\mathrm{Si}$ atoms. The changes in IR frequency saturate at $850^{\circ} \mathrm{C}$. After that, the tunnel oxide layer is mainly composed of stoichiometric $\mathrm{SiO}_{2}$ (or $\mathrm{Si}-\mathrm{O}_{4}$ ). Here, saturation of $x$ at $850^{\circ} \mathrm{C}$ is in good agreement with the maximum $\tau_{\text {eff }}$ obtained at $850^{\circ} \mathrm{C}$ in Figure $1 \mathrm{c}$.
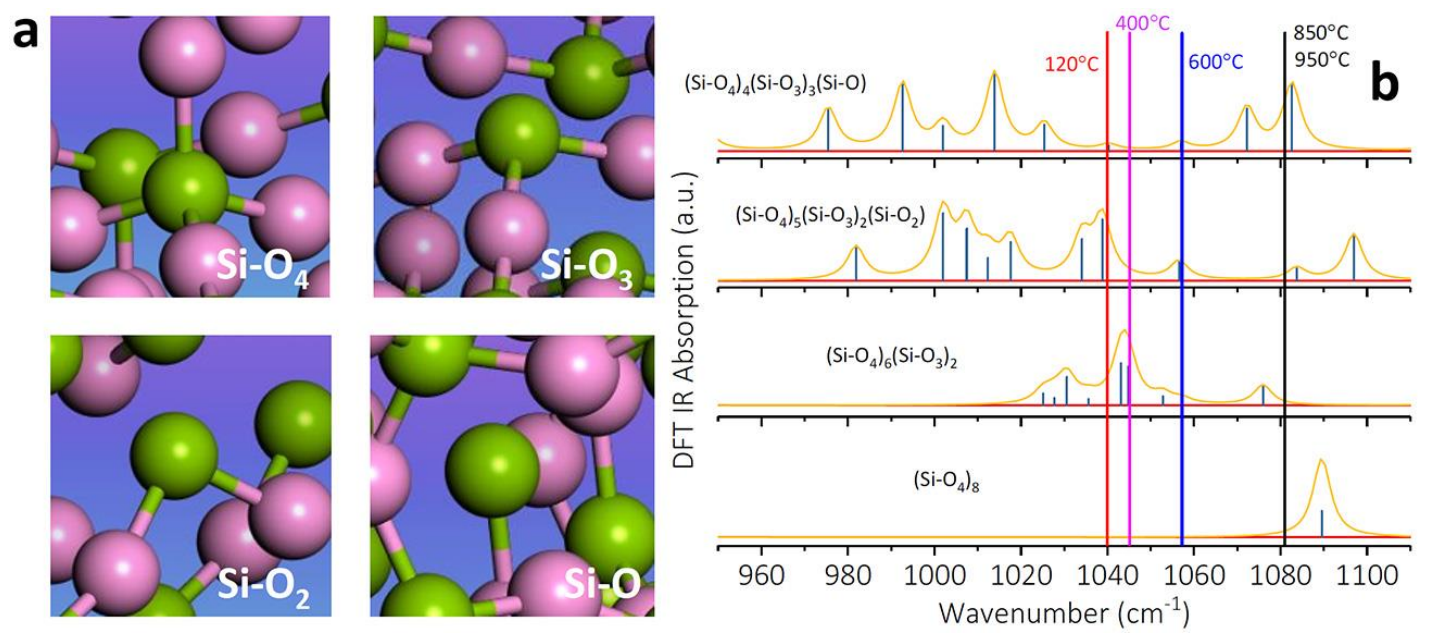

Figure 3. (a) Atomic structures of $\mathrm{Si}-\mathrm{O}_{x}(x=1,2,3,4)$, where green balls represent $\mathrm{Si}$ atoms and violet balls represent $\mathrm{O}$ atoms, the subscript $x$ is the adjacent number of $\mathrm{O}$ atoms bonding to a $\mathrm{Si}$ atom. (b) Theoretical Si-O FTIR spectra of four typical structures $\left(\mathrm{Si}-\mathrm{O}_{4}\right)_{8},\left(\mathrm{Si}-\mathrm{O}_{4}\right)_{6}\left(\mathrm{Si}-\mathrm{O}_{3}\right)_{2},\left(\mathrm{Si}-\mathrm{O}_{4}\right)_{5}\left(\mathrm{Si}_{-} \mathrm{O}_{3}\right)_{2}\left(\mathrm{Si}-\mathrm{O}_{2}\right)$, and $\left(\mathrm{Si}-\mathrm{O}_{4}\right)_{4}\left(\mathrm{Si}-\mathrm{O}_{3}\right)_{3}(\mathrm{Si}-\mathrm{O})$, predicted by DFT calculations using GGA-PBE exchange-correlation pseudopotential.

The rapid $\tau_{\text {eff }}$ increase from $600^{\circ} \mathrm{C}$ to $850^{\circ} \mathrm{C}$ is believed to be determined by either chemical passivation from $\mathrm{SiO}_{x}$ (i.e. reduction of surface states) or (electrical) field-effect passivation (i.e. repelling one type of carrier). ${ }^{55}$ The latter is due to substitutional doping of $\mathrm{B} / \mathrm{P}$ atoms into the $c$ Si network ${ }^{56}$ and formation of a ( $p$ - $n$ or high-low) junction. Although $a$-Si:H starts to crystallize 
between $600^{\circ} \mathrm{C}$ to $700^{\circ} \mathrm{C},{ }^{57} \tau_{\text {eff }}$ is still on a low level $\left(<500 \mu\right.$ s) after $800^{\circ} \mathrm{C}$ annealing for the samples with doped PECVD $a$-Si:H layers (see Figure 1c). Besides, the $\tau_{\text {eff variation trend for }}$ both poly-Si(n)/SiO$x$ and poly-Si $(p) / \mathrm{SiO}_{x}$ samples are identical, featuring a maximum and minimum $\tau_{\text {eff }}$ at the same temperatures. Taking into account the fact that the diffusion of B and $\mathrm{P}$ atoms has different activation energies in $c-\mathrm{Si}^{58}$ we infer that the best passivation at $850^{\circ} \mathrm{C}$ must mainly stem from chemical passivation from $\mathrm{SiO}_{x}$. This is also supported by the fact that the structure without an interfacial tunnel oxide layer does not show an $\tau_{\text {eff }}$ maximum at $\sim 850^{\circ} \mathrm{C}$ in Figure 1c. Additionally, in our experiments, we also find that annealing $\mathrm{SiN}_{x} \mathrm{H}_{y} / \mathrm{poly}-\mathrm{Si}(n) / c$ $\mathrm{Si} /$ poly-Si( $(n) / \mathrm{SiN}_{x} \mathrm{H}_{y}$ at $500^{\circ} \mathrm{C}$ efficiently enhances the $\tau_{\text {eff }}$ from $<100 \mu$ s to $>300 \mu \mathrm{s}$. It is noted that high temperature induced dopant diffusion through $\mathrm{SiO}_{x}$ into $\mathrm{Si}$ wafer also affects the passivation in some extent. ${ }^{59}$ First, the diffused dopant atoms cause defects at $\mathrm{SiO}_{x} / c$-Si interface. Further, they contribute to form a diffused junction that manifests field-effect passivation. Besides the $\mathrm{SiO}_{x}$ structural reconstruction observed herein, $\mathrm{H}$ passivation may also play a role in the passivation, by forming Si-OH groups. ${ }^{60}$ Further study should be conducted to elucidate this speculation.

3.3. Charge States in $\mathrm{SiO}_{x}$ Tunnel Layer. Stegemann et al reported surface photo voltage (SPV) data of $\mathrm{SiO}_{x}$ on crystalline surface, formed in boiling $\mathrm{HNO}_{3} .{ }^{61}$ There exists a defect level $0.18 \mathrm{eV}$ above the Fermi level $(0.38 \mathrm{eV}$ below conduction band minimum). This is actually an acceptor level by $0 .{ }^{62}$ The sample in Ref. 61 is fabricated under the same condition as in the present work. Its position at $E-E_{\mathrm{i}}=0.18 \mathrm{eV}$ unambiguously demonstrates that the $\mathrm{SiO}_{x}$ tunnel layer introduces acceptor-like defects at the $\mathrm{SiO}_{x} / c$-Si interface. The high $D_{\text {it }}\left(\sim 10^{13} \mathrm{~cm}^{-2} \mathrm{eV}^{-1}-\right.$ $10^{14} \mathrm{~cm}^{-2} \mathrm{eV}^{-1}$ ) explains why as-deposited a-Si:H or poly-Si structures with $\mathrm{SiO}_{x}$ tunnel layer always have a low $\tau_{\text {eff }} \sim 3 \mu$ s, whereas the ones without $\mathrm{SiO}_{x}$ tunnel layer have relatively high $\tau_{\text {eff }}>100 \mu \mathrm{s}$. Furthermore, the annealing process at $850^{\circ} \mathrm{C}$, which enhance the $\tau_{\text {eff }}$ up to $>5 \mathrm{~ms}$, once again demonstrates the speculation of $\mathrm{SiO}_{x}$ reconstruction at high temperatures.

3.4. Nano-Pit and Pinhole Formation in $\mathrm{SiO}_{x}$ Films. FTIR measurements have demonstrated that post-annealing induces reconstruction within the $\mathrm{SiO}_{x}$ tunnel layer. Choi et al investigated the structural evolution of poly-Si/SiO $x$ contact structures by HR-TEM, from which they observed the nano-pit-like structure in the tunnel oxide layer, when annealed at a high 
temperature. ${ }^{34}$ This nano-pit feature is of significant importance for carrier transport, affecting the tunneling probability (which increases with decreasing $\mathrm{SiO}_{x}$ thickness), especially for lowlydoped poly-Si structures (see simulated results in Supporting Information Figures S6-S9). Figures $4 \mathrm{a}$ and $4 \mathrm{~b}$ give cross-sectional HR-TEM images of poly-Si/SiO $x / c-\mathrm{Si}$ structures (by PECVD) annealed at $800^{\circ} \mathrm{C}$ and $900^{\circ} \mathrm{C}$ for $30 \mathrm{~min}$, respectively. Clearly, with lower-temperature $\left(800^{\circ} \mathrm{C}\right)$ annealing, the poly-Si/SiO${ }_{x} / c$-Si structure shows uniform interfaces at both sides of the tunnel layer (Figure 4a). However, higher temperature $\left(900^{\circ} \mathrm{C}\right)$ annealing results in significant morphological changes in the $\mathrm{SiO}_{x}$ tunnel layer (Figure 4b). As examples, the arrows $\mathrm{P} 1$ in Figure $4 \mathrm{~b}$ indicate the presence of nano-pits on the poly-Si side, and the arrow P2 is a nano-pit on the $c$-Si side. These nano-pits likely play an important role in the carrier transport for poly$\mathrm{Si} / \mathrm{SiO}_{x}$ contact solar cells, because they enable more efficient carrier tunneling. Furthermore, we also observe some pinholes even penetrating the complete $\mathrm{SiO}_{x}$ tunnel layer (arrows $\mathrm{P} 3$ in Figure 4b). A moderate pinhole density might contribute to better carrier transport, but a very high density can be detrimental because of significant doping-atom (P/B) leakage into the $c-\mathrm{Si}$ substrate during annealing. ${ }^{63-64}$ Figure $4 \mathrm{c}$ shows the c-AFM image measured on a poly-Si/SiO $x / c$ $\mathrm{Si}$ sample annealed at $850^{\circ} \mathrm{C}$ for $30 \mathrm{~min}$. The current curve demonstrates that the measured current can vary significanly, with lower values between pinholes. We find that some small points (small diameter) enable very high current (small bright points in Figure 4c), but some larger points (large diameter) have lower current (large green points in Figure 4c). We speculate that these green points probably correspond to nano-pits. In such nano-pits, the $\mathrm{SiO}_{x}$ tunnel layer is still present, but can locally be much thinner than elsewhere, the thinner $\mathrm{SiO}_{x}$ tunnel layer in the nano-pit regions make the tunnelling current higher than in the peripheral regions. However, these current values are still smaller than those in pinhole regions, where no $\mathrm{SiO}_{x}$ tunnel layer is anymore present. Figures $4 \mathrm{~d}$ and $4 \mathrm{e}$ are contact resistivity data for poly-Si/ $\mathrm{SiO}_{x} / \mathrm{c}$-Si samples annealed at $800^{\circ} \mathrm{C}$ and $850^{\circ} \mathrm{C}$ respectively. Apparent contact resistivity reduction is observed from $37 \mathrm{~m} \Omega \cdot \mathrm{cm}^{2}$ to $4.5 \mathrm{~m} \Omega \cdot \mathrm{cm}^{2}$. This trend supports our transport speculation from HR-TEM measurements. However, we cannot anneal the sample at too high temperature, because severe $\mathrm{P} / \mathrm{B}$ leakage would result in poor chemical passivation. 

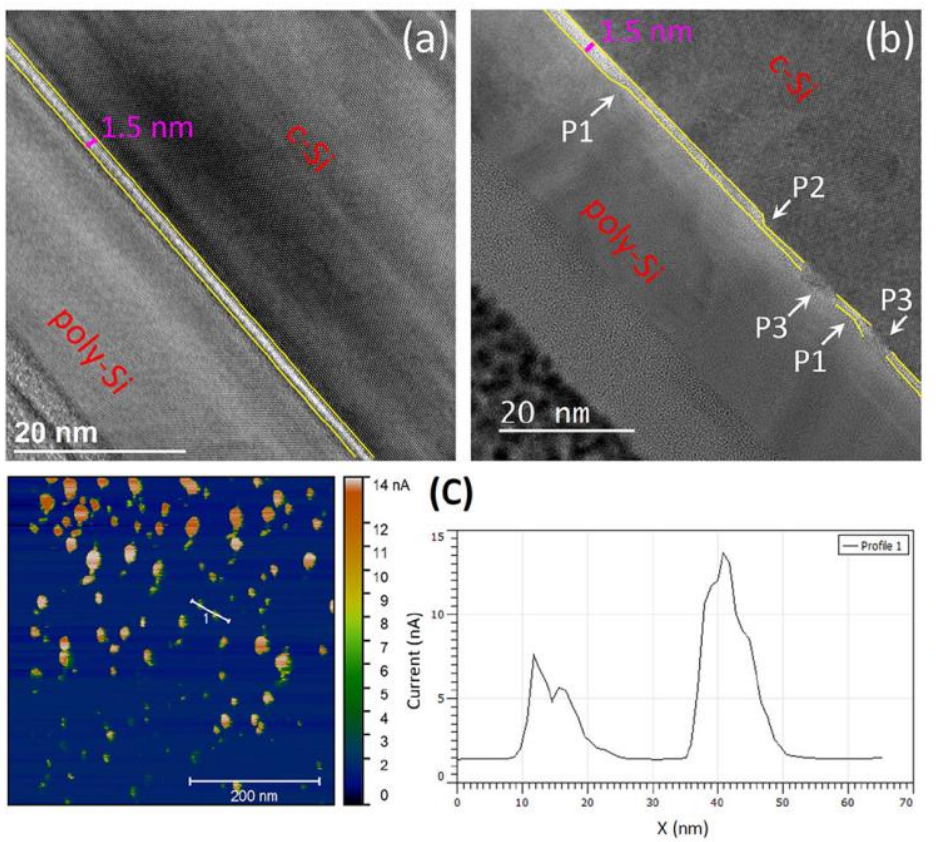
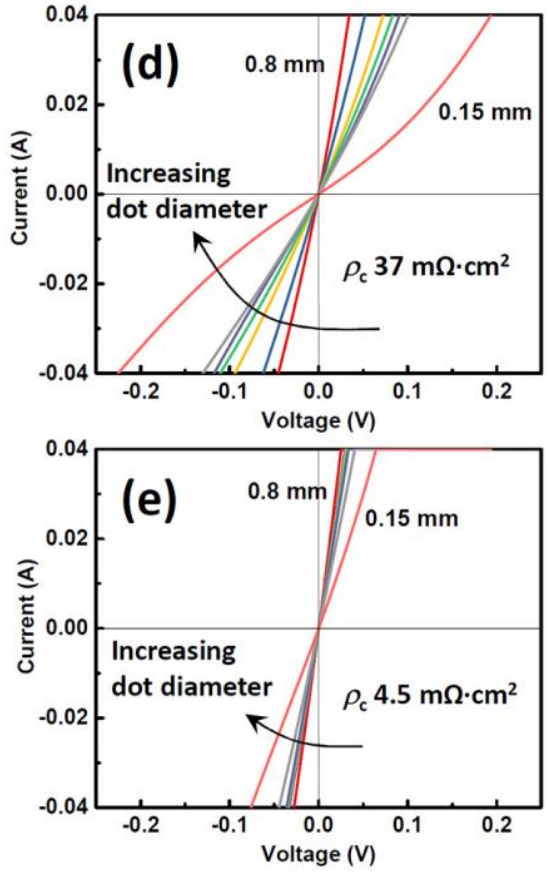

Figure 4. Cross-sectional HR-TEM images of poly-Si/SiO $x / \mathrm{c}-\mathrm{Si}$ annealed at (a) $800^{\circ} \mathrm{C}$ and (b) $900^{\circ} \mathrm{C}$. The annealing time for both samples is $30 \mathrm{~min}$, (c) c-AFM image from the poly-Si/SiOx/c-Si sample annealed at $850^{\circ} \mathrm{C}$ for $30 \mathrm{~min}$, where the current curve is plotted along the white line in the image (labeled 1 in the figure). (d) and (e) are contact resistivity data for poly-Si/SiO $/ / \mathrm{c}$-Si samples annealed at $800^{\circ} \mathrm{C}$ and $850^{\circ} \mathrm{C}$ respectively. The data in (d) indicates it is not a perfect ohmic contact.

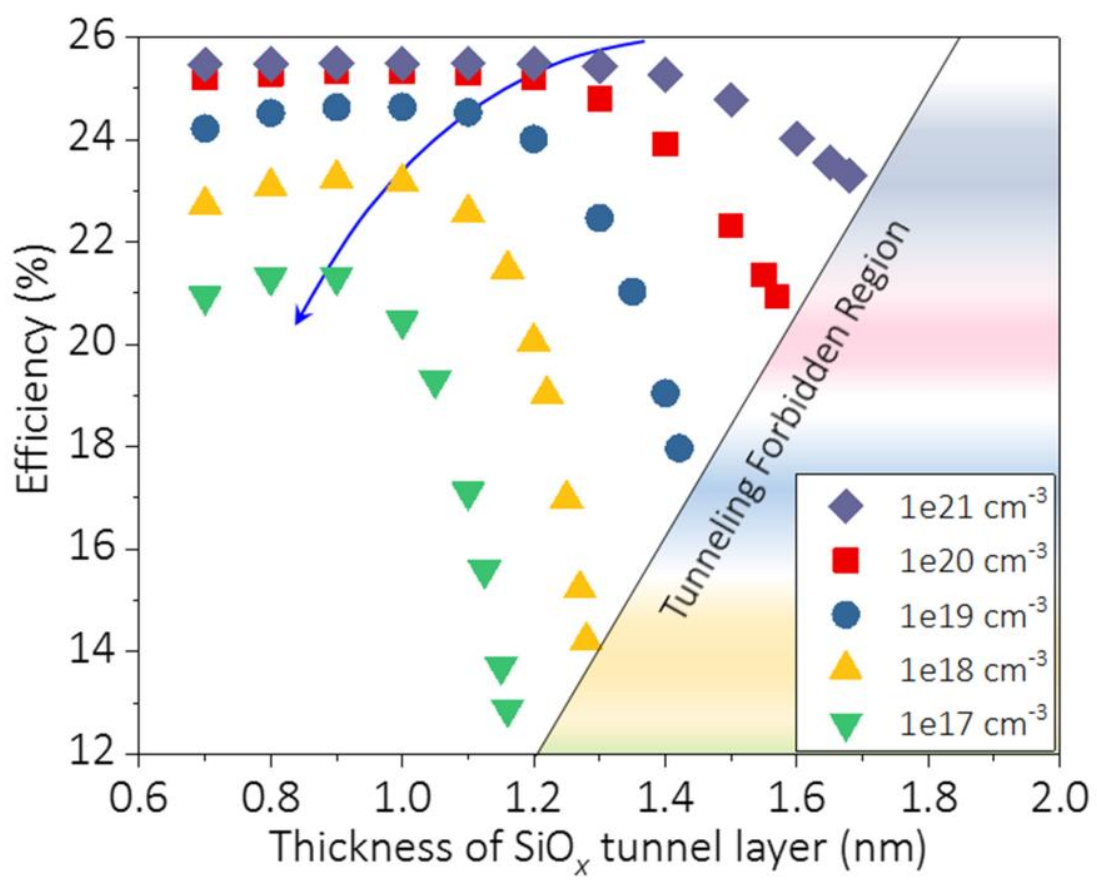


Figure 5. Theoretical efficiency of poly-Si/SiO$x$ passivating contact solar cell as a function of $\mathrm{SiO}_{x}$ thickness. The blue arrow indicates that lowly-doped poly-Si $(n)$ requires thinner $\mathrm{SiO}_{x}$ tunnel layers to obtain optimal efficiency. The simulated device has a boron diffused front $p^{+}$emitter and an $n$-type poly-silicon rear contact.

Figure 5 shows the simulated dependence of the theoretical efficiencies of solar cell with poly-Si $(n) / \mathrm{SiO}_{x}$ passivating rear contact (Figure 6a) on tunnel $\mathrm{SiO}_{x}$ thickness. The results indicate that to maximize the efficiency, the tunnel oxide thickness should be made thinner for lower doped poly-Si( $n)$ structures. At a high doping concentration of $\sim 1 \times 10^{21} \mathrm{~cm}^{-3}$ in the poly$\mathrm{Si}(n)$ layer, the maximum $\mathrm{SiO}_{x}$ thickness for a working device requires the thickness not more than $\sim 1.7 \mathrm{~nm}$; the maximum efficiency is reached at a $\mathrm{SiO}_{x}$ thickness of $\sim 1.3 \mathrm{~nm}$. However, with a reduced doping concentration of $\sim 1 \times 10^{17} \mathrm{~cm}^{-3}$ in the poly-Si(n) layer, the 'threshold' $\mathrm{SiO}_{x}$ thickness for the device to function becomes narrower $(\sim 1.1 \mathrm{~nm})$; the optimal thickness in that case also decreases to $\sim 0.9 \mathrm{~nm}$. These theoretical results may explain why experimental highefficiency $c$-Si solar cells have been reported with different $\mathrm{SiO}_{x}$ thicknesses, ranging from 1.1 to $1.7 \mathrm{~nm} .{ }^{21,47,63,65-66}$ It is noteworthy that the simulations in this work did not take into account the shallow diffusion into the $c$-Si wafer from the poly-Si $(n)$ layer. Accounting for a slight doping tail into the $c$-Si wafer may increase the tunneling probability, and alter our results slightly but not fundamentally. Another point we should point out herein is that for $\mathrm{SiO}_{x} / c-\mathrm{Si}$ system, the interface is not abrupt, ${ }^{67-68}$ which means that the assumptive optical and electrical constants for $\mathrm{SiO}_{x}$ is not accurate. Therefore, it is a qualitative analysis between carrier tunnelling and thickness and doping concentration of $\mathrm{SiO}_{x}$ layer. 

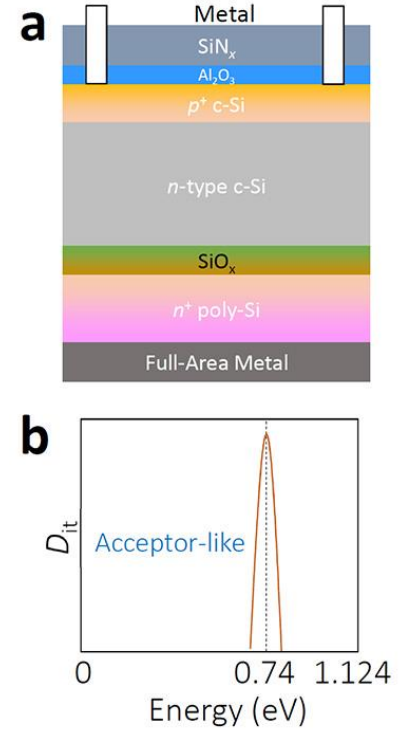
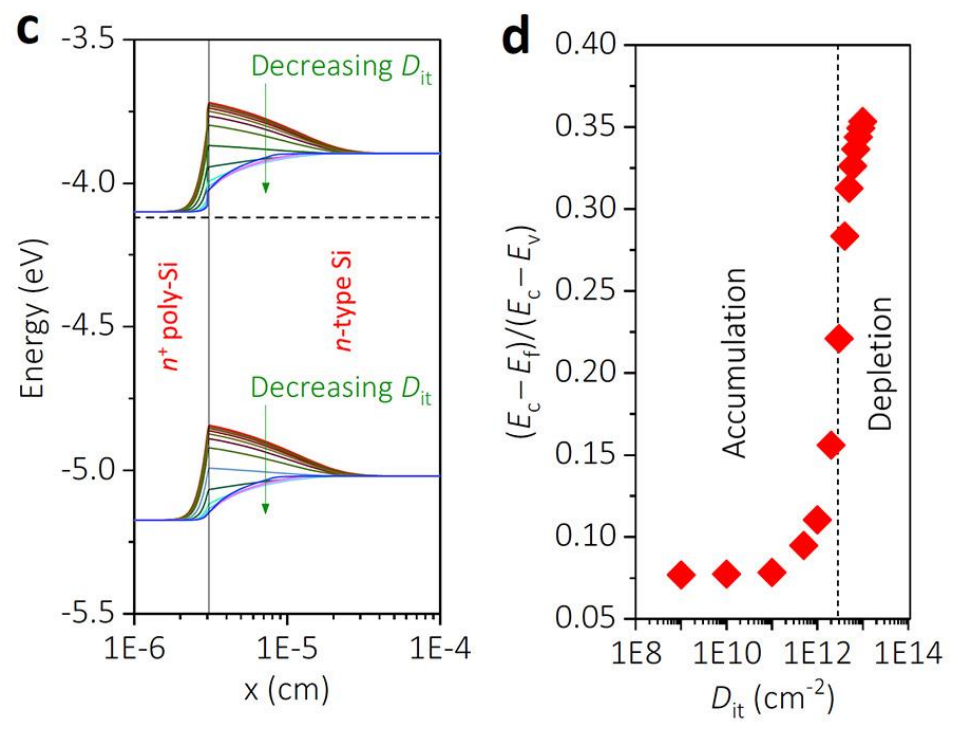

Figure 6. (a) Schematic of simulated cell in AFORS-HET v2.5; (b) Narrow Gaussian $n^{+}$poly-Si $/ c-\mathrm{Si}$ interface acceptor-like defects locating at $E-E_{\mathrm{i}}=0.18 \mathrm{eV}$; (c) Band bending at the $n^{+}$poly-Si/c-Si interface with variable $D_{\text {it }}$ from $1 \times 10^{9} \mathrm{~cm}^{-2}$ to $1 \times 10^{13} \mathrm{~cm}^{-2}$; (d) $\left[E_{\mathrm{c}}-E_{\mathrm{f}}\right] /\left[E_{\mathrm{c}}-E_{\mathrm{v}}\right]$ at the $n^{+}$poly-Si $/ c-\mathrm{Si}$ interface plotted as a function of $D_{\mathrm{it}}$.

3.5. Carrier Transport Mechanism. Thus far, we have shown how oxygen introduces acceptor-like defect levels locating at $E-E_{\mathrm{i}}=0.18 \mathrm{eV}$ in $\mathrm{SiO}_{x}$ tunnel layer, and how the nano-pit characteristics in the $\mathrm{SiO}_{x}$ tunnel layer can be changed via optimizing annealing temperature. Next, effect of $D_{\mathrm{it}}$ and the pinhole density, $D_{\mathrm{ph}}$, of the $\mathrm{SiO}_{x}$ tunnel layer on the solar cell performance is investigated by simulation. Figure 6a shows the simulated device, which features a boron diffused $p^{+}$emitter at front and a full-area poly- $\mathrm{Si}(n) / \mathrm{SiO}_{x}$ passivating contact at the rear. The $\mathrm{O}$ related acceptor-like state is schematically displayed in Figure 6b. Figure 6c shows the band alignment at the rear poly-Si passivating contact interface. Clearly, a high $D_{\text {it }}$ is detrimental to electron transport due to appearance of a broad and high electron barrier at conduction band minimum. This barrier can be reduced or even eliminated by effective chemical passivation, as demonstrated in Figure 6c. We plot the ratio of $\left(E_{\mathrm{c}}-E_{\mathrm{f}}\right) /\left(E_{\mathrm{c}}-E_{\mathrm{v}}\right)$ at rear interface as a function of $D_{\text {it }}$ in Figure 6d. It is noted, when $D_{\text {it }}>6 \times 10^{12} \mathrm{~cm}^{-2}$, the Fermi level is pinned at $\left(E_{\mathrm{c}}-E_{\mathrm{f}}\right) /\left(E_{\mathrm{c}}-E_{\mathrm{v}}\right)$ $\sim 1 / 3$. An electron depletion region is formed on $n$-Si surface, which leads to an inverted surface electric field, impeding electron transport. As $D_{\text {it }}$ gradually reduces to $3 \times 10^{12} \mathrm{~cm}^{-2}$, the electron barrier flattens, and consequently electrons start to accumulate at $n$-Si surface. A high-low junction is formed in this scenario. Around the critical $D_{\mathrm{it}}$ value of $\sim 3 \times 10^{12} \mathrm{~cm}^{-2},\left(E_{\mathrm{c}}-E_{\mathrm{f}}\right) /\left(E_{\mathrm{c}}-E_{\mathrm{v}}\right)$ sharply decreases from 0.28 to 0.16 , corresponding to $D_{\text {it }}$ decreases in a narrow range from 
$4 \times 10^{12} \mathrm{~cm}^{-2}$ to $2 \times 10^{12} \mathrm{~cm}^{-2}$. A further decrease in $D_{\text {it }}$ to $\sim 1 \times 10^{11} \mathrm{~cm}^{-2},\left(E_{\mathrm{c}}-E_{\mathrm{f}}\right) /\left(E_{\mathrm{c}}-E_{\mathrm{v}}\right)$ is found to saturate at 0.077 , indicating $D_{\mathrm{it}}=1 \times 10^{11} \mathrm{~cm}^{-2}$ is sufficiently low to enable excellent passivation. Figures $8 \mathrm{a}-8 \mathrm{~d}$ show the dependence of device performance on the pinhole characteristics $\left(D_{\mathrm{it}}\right.$ and $\left.D_{\mathrm{ph}}\right)$. It is interesting to see that $J_{\mathrm{sc}}, \mathrm{FF}$ and PEC $\left(E_{\mathrm{ff}}\right)$ increase with increasing $D_{\mathrm{ph}}$ at high defect region $D_{\mathrm{it}} \sim 1 \times 10^{13} \mathrm{~cm}^{-2}$. A moderate PEC of $\sim 18 \%$ can be obtained when $D_{\mathrm{ph}}>0.01$, which suggests pinhole current dominates the cell performance when the poly-Si/c-Si interface is poorly passivated. In the middle $D_{\text {it }}$ region from $10^{13} \mathrm{~cm}^{-2}$ to $10^{11} \mathrm{~cm}^{-2}$, all of the device parameters are monotonously enhanced with decreasing values for $D_{\mathrm{it}}$, thanks to the improved surface passivation. In contrast, the device performance relies significantly on both $D_{\text {it }}$ and $D_{\text {ph }}$ when the $D_{\text {it }}<1 \times 10^{11} \mathrm{~cm}^{-2}$, featuring an improved $V_{\mathrm{oc}}, J_{\mathrm{sc}}$, FF and $E_{\mathrm{ff}}$ with decreasing $D_{\mathrm{ph}}$. These simulation results indicate the device working principle has changed from pinhole-dominated to tunneling-dominated. Decreasing the pinhole density in $\mathrm{SiO}_{x}$ tunnel layer under this condition results in a better carrier selectivity. The high PEC over $22.5 \%$ at $D_{\mathrm{it}}<1 \times 10^{11} \mathrm{~cm}^{-2}$ shown in figure $7 \mathrm{~d}$ is in good consistent with the results given in Figure $6 \mathrm{~d}$.
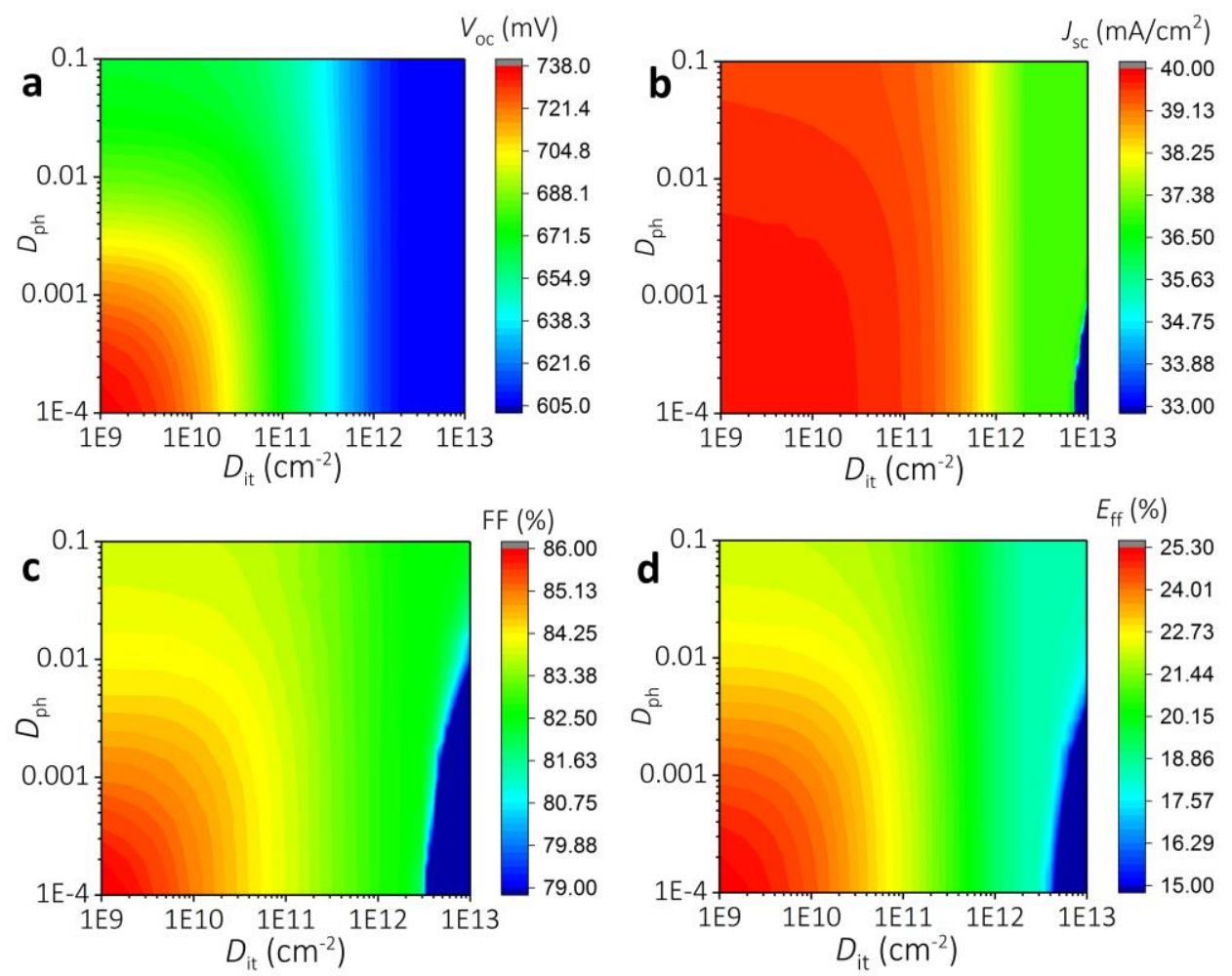

Figure 7. (a)-(d) are calculated $V_{\mathrm{oc}}, J_{\mathrm{sc}}, \mathrm{FF}$ and $E_{\mathrm{ff}}$ plotted against $D_{\mathrm{it}}$ and $D_{\mathrm{ph}}$, which are changed in the range of $1 \times 10^{9} \mathrm{~cm}^{-2}-1 \times 10^{13} \mathrm{~cm}^{-2}$ and $1 \times 10^{-4}-1 \times 10^{-1}$ respectively. 


\section{CONCLUSION}

Two passivation mechanisms are identified for poly-Si/SiO${ }_{x}$ passivating contact under different annealing temperature regions. At the low annealing temperature range $\left(<600^{\circ} \mathrm{C}\right)$, the surface passivation is dominated by hydrogen passivation, whereas $\mathrm{SiO}_{x}$ chemical passivation turns to be the dominant factor at high annealing temperatures $\left(\sim 850^{\circ} \mathrm{C}\right)$. FTIR spectra demonstrate that the under-stoichiometric $\mathrm{O}$, present in chemically-grown $\mathrm{SiO}_{x}$ are negative charged and bond to unsaturated $\mathrm{Si}$ atoms during high-temperature annealing. The structural evolution of the $\mathrm{SiO}_{x}$ tunnel layer effectively unpins the Fermi level at poly-Si/c-Si interface. The low contact resistance and high surface passivation of the poly-Si/SiO ${ }_{x}$ passivating contact annealed at the temperature of $\sim 850^{\circ} \mathrm{C}$ can be attributed to the formation of 'nano-pits' within the re-constructed $\mathrm{SiO}_{x}$ tunnel layer, which maintains a low interface defect state density. Tunneling simulations unveil that the pinhole current dominates the device performance when the poly-Si/SiO $x$ passivating contact shows a poor surface passivation at high temperature annealing $\left(>850^{\circ} \mathrm{C}\right)$. In contrast, tunneling becomes the dominant carrier transport mechanism when the passivation of poly-Si/SiO $x$ contact is good enough. This occurs at the optimized annealing temperature $\sim 850^{\circ} \mathrm{C}$.

\section{ASSOCIATED CONTENT}

\section{Supporting Information}

The Supporting Information is available: Additional calculation details presented as Table S1, Figures S1-S9.

\section{AUTHOR INFORMATION}

\section{Corresponding Author}

*W. Liu. E-mail: wenzhu.liu@kaust.edu.sa.

*S. De Wolf. E-mail: stefaan.dewolf@kaust.edu.sa.

\section{Author Contributions}


$¥$ These authors contributed equally to this work. The manuscript was written through contributions of all authors. All authors have given approval to the final version of the manuscript.

\section{Notes}

The authors declare no competing financial interest.

\section{ACKNOWLEDGEMENTS}

W. L. would like to acknowledge Jiajia Ling, Dr. Jichun Ye and Dr. Yuheng Zeng for their assistance in modeling poly-Si/SiO $x$ passivating contact solar cell in AFORS-HET v2.5. The authors also acknowledge Yifan Dang for resistivity measurements. The research reported in this publication was supported by funding from King Abdullah University of Science and Technology (KAUST) Office of Sponsored Research (OSR) under award no. OSR-CRG $\mathrm{URF} / 1 / 3383$.

\section{REFERENCES}

(1) Jäger-Waldau, A. Snapshot of photovoltaics - February 2018, EPJ Photovolt. 2018, 9, 1-6.

(2) Fraunhofer Institute for Solar Energy Systems, Photovoltaics-Report 2018, 1-47.

(3) Green, M. A.; The Passivated Emitter and Rear Cell (PERC): From conception to mass production. Sol.Energy Mater. Sol. Cells 2015, 143, 190-197.

(4) Chen, C. C.; Dou, L. T.; Zhu, R.; Chung, C. H.; Song, T. B.; Zheng, Y. B.; Hawks, S.; Li, G.; Weiss, P. S.; Yang, Y. Visibly Transparent Polymer Solar Cells Produced by Solution Processing. Acs Nano 2012, 6, 7185-7190.

(5) Battaglia, C.; Cuevas, A.; De Wolf, S. High-efficiency crystalline silicon solar cells: status and perspectives. Energy \& Environmental Sci. 2016, 9, 1552-1576.

(6) Yoshikawa, K.; Yoshida, W.; Irie, T.; Kawasaki, H.; Konishi, K.; Ishibashi, H.; Asatani, T.; Adachi, D.; Kanematsu, M.; Uzu, H.; Yamamoto, K. Exceeding conversion efficiency of $26 \%$ by heterojunction interdigitated back contact solar cell with thin film Si technology. Sol. Energy Mater. Sol. Cells 2017, 173, 37-42.

(7) Liu, W.; Meng, F.; Zhang, X.; Liu, Z. Evolution of a Native Oxide Layer at the a-Si:H/c-Si Interface and Its Influence on a Silicon Heterojunction Solar Cell. ACS Appl Mater Interfaces 2015, 7, $26522-26529$. 
(8) Masuko, K.; Shigematsu, M.; Hashiguchi, T.; Fujishima, D.; Kai, M.; Yoshimura, N.; Yamaguchi, T.; Ichihashi, Y.; Mishima, T.; Matsubara, N.; Yamanishi, T.; Takahama, T.; Taguchi, M.; Maruyama, E.; Okamoto, S. Achievement of More Than 25\% Conversion Efficiency With Crystalline Silicon Heterojunction Solar Cell. IEEE J. Photovolt. 2014, 4, 1433-1435.

(9) Liu, W.; Zhang, L.; Chen, R.; Meng, F.; Guo, W.; Bao, J.; Liu, Z. Underdense a-Si:H film capped by a dense film as the passivation layer of a silicon heterojunction solar cell. J. Appl. Phys. 2016, 120, 175301.

(10) Taguchi, M.; Yano, A.; Tohoda, S.; Matsuyama, K.; Nakamura, Y.; Nishiwaki, T.; Fujita, K.; Maruyama, E. 24.7\% Record Efficiency HIT Solar Cell on Thin Silicon Wafer. IEEE J. Photovolt. 2014, 4, 96-99.

(11) Liu, W.; Zhang, L.; Cong, S.; Chen, R.; Wu, Z.; Meng, F.; Shi, Q.; Liu, Z. Controllable a-Si:H/c-Si interface passivation by residual SiH 4 molecules in $\mathrm{H} 2$ plasma. Sol. Energy Mater. Sol. Cells 2018, 174, 233-239.

(12) Adachi, D.; Hernández, J. L.; Yamamoto, K. Impact of carrier recombination on fill factor for large area heterojunction crystalline silicon solar cell with 25.1\% efficiency. Appl. Phys. Lett. 2015, 107, 2335065.

(13) Liu, W.; Zhang, L.; Meng, F.; Guo, W.; Bao, J.; Liu, J.; Wang, D.; Liu, Z. Characterization of microvoids in thin hydrogenated amorphous silicon layers by spectroscopic ellipsometry and Fourier transform infrared spectroscopy. Scripta Materialia 2015, 107, 50-53.

(14) De Wolf, S.; Descoeudres, A.; Holman, Z. C.; Ballif, C. High-efficiency Silicon Heterojunction Solar Cells: A Review. green 2012, 2, 7-24.

(15) Yang, X.; Weber, K.; Hameiri, Z.; De Wolf, S. Industrially feasible, dopant-free, carrier-selective contacts for high-efficiency silicon solar cells. Prog. Photovolt.: Research and Appl. 2017, 25, 896-904.

(16) Geissbühler, J.; Werner, J.; Martin de Nicolas, S.; Barraud, L.; Hessler-Wyser, A.; Despeisse, M.; Nicolay, S.; Tomasi, A.; Niesen, B.; De Wolf, S.; Ballif, C. $22.5 \%$ efficient silicon heterojunction solar cell with molybdenum oxide hole collector. Appl. Phys. Lett. 2015, 107, 081605.

(17) Schmidt, J.; Titova, V.; Zielke, D. Organic-silicon heterojunction solar cells: Open-circuit voltage potential and stability. Appl. Phys. Lett. 2013, 103, 183901.

(18) Yang, X.; Bi, Q.; Ali, H.; Davis, K.; Schoenfeld, W. V.; Weber, K. High-Performance TiO2 -Based Electron-Selective Contacts for Crystalline Silicon Solar Cells. Adv Mater 2016, 28, 5891-5897.

(19) Bullock, J.; Zheng, P. T.; Jeangros, Q.; Tosun, M.; Hettick, M.; Sutter-Fella, C. M.; Wan, Y.; Allen, T.; Yan, D.; Macdonald, D.; De Wolf, S.; Hessler-Wyser, A.; Cuevas, A.; Javey, A. Lithium 
Fluoride Based Electron Contacts for High Efficiency n-Type Crystalline Silicon Solar Cells. Adv. Energy Mater. 2016, 6, 1600241.

(20) Yang, X.; Aydin, E.; Xu, H.; Kang, J.; Hedhili, M.; Liu, W.; Wan, Y.; Peng, J.; Samundsett, C.; Cuevas, A.; De Wolf, S. Tantalum Nitride Electron-Selective Contact for Crystalline Silicon Solar Cells. Adv. Energy Mater. 2018, 8, 1800608 1-7.

(21) Feldmann, F.; Bivour, M.; Reichel, C.; Hermle, M.; Glunz, S. W. Passivated rear contacts for highefficiency n-type Si solar cells providing high interface passivation quality and excellent transport characteristics. Sol. Energy Mater. Sol. Cells 2014, 120, 270-274.

(22) Krügener, J.; Haase, F.; Rienäcker, M.; Brendel, R.; Osten, H. J.; Peibst, R. Improvement of the SRH bulk lifetime upon formation of n-type POLO junctions for $25 \%$ efficient Si solar cells. Sol. Energy Mater. Sol. Cells 2017, 173, 85-91.

(23) Richter, A.; Benick, J.; Feldmann, F.; Fell, A.; Hermle, M.; Glunz, S. W. n-Type Si solar cells with passivating electron contact: Identifying sources for efficiency limitations by wafer thickness and resistivity variation. Sol. Energy Mater. Sol. Cells 2017, 173, 96-105.

(24) Yan, D.; Cuevas, A.; Bullock, J.; Wan, Y.; Samundsett, C. Phosphorus-diffused polysilicon contacts for solar cells. Sol. Energy Mater. Sol. Cells 2015, 142, 75-82.

(25) Maydell, K.V.; Korte, L.; Laades, A.; Stangl, R.; Conrad, E.; Lange, F.; Schmidt, M. Characterization and optimization of the interface quality in amorphous/crystalline silicon heterojunction solar cells. J. Non-Cryst. Solids 2006, 352, 1958-1961.

(26) Fujiwara, H.; Kaneko, T.; Kondo, M.; Optimization of interface structures in crystalline silicon heterojunction solar cells. Sol. Energy Mater. Sol. Cells 2009, 93, 725-728.

(27) Holman, Z. C.; Descoeudres, A.; Barraud, L.; Fernandez, F. Z.; Seif, J. P.; De Wolf, S.; Ballif, C. Current Losses at the Front of Silicon Heterojunction Solar Cells. IEEE J. Photovolt. 2012, 2, 7-15.

(28) Römer, U.; Peibst, R.; Ohrdes, T.; Lim, B.; Krügener, J.; Bugiel, E.; Wietler, T.; Brendel, R. Recombination behavior and contact resistance of $\mathrm{n}+$ and $\mathrm{p}+$ poly-crystalline $\mathrm{Si} /$ mono-crystalline $\mathrm{Si}$ junctions. Sol. Energy Mater. Sol. Cells 2014, 131, 85-91.

(29) Glunz, S. W.; Feldmann, F. $\mathrm{SiO}_{2}$ surface passivation layers - a key technology for silicon solar cells. Sol. Energy Mater. Sol. Cells 2018, 185, 260-269.

(30) Moldovan, A.; Feldmann, F.; Zimmer, M.; Rentsch, J.; Benick, J.; Hermle, M. Tunnel oxide passivated carrier-selective contacts based on ultra-thin $\mathrm{SiO}_{2}$ layers. Sol. Energy Mater. Sol. Cells 2015, 142, 123-127.

(31) Peibst, R.; Romer, U.; Larionova, Y.; Rienacker, M.; Merkle, A.; Folchert, N.; Reiter, S.; Turcu, M.; Min, B.; Krugener, J.; Tetzlaff, D.; Bugiel, E.; Wietler, T.; Brendel, R. Working principle of carrier 
selective poly-Si/c-Si junctions: Is tunnelling the whole story? Sol. Energy Mater. Sol. Cells 2016, $158,60-67$.

(32) Tetzlaff, D.; Krügener, J.; Larionova, Y.; Reiter, S.; Turcu, M.; Haase, F.; Brendel, R.; Peibst, R.; Höhne, U.; Kähler, J. D.; Wietler, T. F. A simple method for pinhole detection in carrier selective POLO-junctions for high efficiency silicon solar cells. Sol. Energy Mater. Sol. Cells 2017, 173, $106-110$.

(33) Steinkemper, H.; Feldmann, F.; Bivour, M.; Hermle, M. Numerical Simulation of Carrier-Selective Electron Contacts Featuring Tunnel Oxides. IEEE J. Photovolt. 2015, 5, 1348-1356.

(34) Choi, S.; Min, K. H.; Jeong, M. S.; Lee, J. I.; Kang, M. G.; Song, H.-E.; Kang, Y.; Lee, H.-S.; Kim, D.; Kim, K.-H. Structural evolution of tunneling oxide passivating contact upon thermal annealing. Sci. Reports 2017, 7, 1-11.

(35) Folchert, N.; Rienäcker, M.; Yeo, A.A.; Min, B.; Peibst, R.; Brendel, R. Temperature-dependent contact resistance of carrier selective Poly-Si on oxide junctions. Sol. Energy Mater. Sol. Cells 2018, $185,425-430$.

(36) Feldmann, F.; Nogay, G.; Löper, P.; Young, D.L.; Lee, B.G.; Stradins, P.; Hermle, M.; Glunz, S.W. Charge carrier transport mechanisms of passivating contacts studied by temperature-dependent J-V measurements. Sol. Energy Mater. Sol. Cells 2018, 178, 15-19.

(37) Kale, A.S.; Nemeth, W.; Guthrey, H.; Kennedy, E.; Norman, A.G.; Page, M.; Al-Jassim, M.; Young, D.L.; Agarwal, S.; Stradins, P.; Understanding the charge transport mechanisms through ultrathin SiOx layers in passivated contacts for high-efficiency silicon solar cells. Appl. Phys. Lett. 2019, 114, 083902.

(38) Ernzerhof, M. ; Scuseria, G.E. Assessment of the Perdew-Burke-Ernzerhof exchange-correlation functional. J. Chem. Phys. 1999, 110, 5029-5036.

(39) Cox, R.H.; Strack, H. Ohmic Contacts for GaAs Devices. Solid-State Electronics, 1967, 10, 1213-1218.

(40) Varache, R.; Leendertz, C.; Gueunier-Farret, M.E.; Haschke, J.; Muñoz, D.; Korte, L. Investigation of selective junctions using a newly developed tunnel current model for solar cell applications. Sol. Energy Mater. Sol Cells, 2015, 141, 14-23.

(41) Mahan, A. H.; Carapella, J.; Nelson, B. P.; Crandall, R. S.; Balberg, I. Deposition of device quality, low H content amorphous silicon. J. Appl. Phys. 1991, 69, 6728-6730.

(42) Kroll, U.; Meier, J.; Shah, A.; Mikhailov, S.; Weber, J. Hydrogen in amorphous and microcrystalline silicon films prepared by hydrogen dilution. J. Appl. Phys. 1996, 80, 4971-4975. 
(43) Conradi, M. S.; Norberg, R. E. Molecular $\mathrm{H}_{2}$ : Nuclear-spin-relaxation centers for protons in a-Si:H. Phys. Rev. B 1981, 24, 2285-2288.

(44) Carlos, W. E.; Taylor, P. C. Hydrogen-Associated Disorder Modes in Amorphous Si:H Films. Phys. Rev. Lett. 1980, 45, 358-362.

(45) Boyce, J. B.; Stutzmann, M. Orientational ordering and melting of molecular $\mathrm{H}_{2}$ in an a-Si matrix: NMR studies. Phys. Rev. Lett. 1985, 54, 562565.

(46) De Wolf, S.; Kondo, M. Boron-doped a-Si:H/c-Si interface passivation: degradation mechanism. Appl. Phys. Lett. 2007, 91, 112109.

(47) Li, Q.; Tao, K.; Sun, Y.; Jia, R.; Wang, S.-M.; Jin, Z.; Liu, X.-Y. Replacing the amorphous silicon thin layer with microcrystalline silicon thin layer in TOPCon solar cells. Sol. Energy 2016, 135, 487-492.

(48) Staebler, D.L.; Wronski, C.R. Optically induced conductivity changes in discharge-produced hydrogenated amorphous silicon. J. Appl. Phys. 1980, 51, 3262-3268.

(49) Yamamoto, T.; Uwasawa, K.; Mogami, T. Bias Temperature Instability in Scaled p Polysilicon Gate p-MOSFET's. IEEE T Electron Dev. 1999, 46, 921-926.

(50) Lucovsky, G.; Nemanich, R. J.; Knights, J. C. Structural interpretation of the vibrational spectra ofaSi: H alloys. Phys. Rev. B 1979, 19, 2064-2073.

(51) Brodsky, M. H.; Cardona, M.; Cuomo, J. J. Infrared and Raman spectra of the silicon-hydrogen bonds in amorphous silicon prepared by glow discharge and sputtering. Phys. Rev. B 1977, 16, $3556-3571$.

(52) Kakalios, J.; Street, R. A.; Jackson, W. B. Stretched-exponential relaxation arising from dispersive diffusion of hydrogen in amorphous silicon. Phys. Rev. Lett. 1987, 59, 1037-1040.

(53) Nakamura, M.; Mochizuki, Y.; Usami, K.; Itoh, Y.; Nozaki, T. Infred Absorption Spectra and Compositions of Evaporated Silicon Oxides $\left(\mathrm{SiO}_{x}\right)$. Solid State Communications, 1984, 50, 1079-1081.

(54) Salh, R.; Czarnowski, A.; Zamoryanskaya, M.V.; Kolesnikova, E.V.; Fitting, H.J.; Cathodoluminescence of SiOx under-stoichiometric silica layers. Phys. stat. sol. (a), 2006, 203, 2049-2057.

(55) Schulz, P.; Cowan, S. R.; Guan, Z. L.; Garcia, A.; Olson, D. C.; Kahn, A. NiOX/MoO3 Bi-Layers as Efficient Hole Extraction Contacts in Organic Solar Cells. Adv. Funct. Mater. 2014, 24, 701-706.

(56) Islam, R.; Ramesh, P.; Nam, J. H.; Saraswat, K. C. Nickel Oxide Carrier Selective Contacts for Silicon Solar Cells. 2015 Ieee 42nd Photovoltaic Specialist Conference (PVSC) 2015. 
(57) Lozac'h, M.; Nunomura, S.; Sai, H.; Matsubara, K. Passivation property of ultrathin SiOx:H/a-Si:H stack layers for solar cell applications. Sol. Energy Mater. Sol. Cells 2018, 185, 8-15.

(58) Csepregi, L.; Kennedy, E. F.; Gallagher, T. J.; Mayer, J. W.; Sigmon, T. W. Reordering of amorphous layers of Si implanted with 31P, 75As, and 11B ions. J. Appl. Phys. 1977, 48, 4234-4240.

(59) Kale, A.S. Nemeth, W.; Harvey, S.P.; Page, M.; Young, D.L.; Agarwala, S.; Stradins, P. Effect of silicon oxide thickness on polysilicon based passivated contacts for high-efficiency crystalline silicon solar cells. Sol. Energy Mater. Sol. Cells, 2018, 185, 270-276.

(60) Robertson, J. Intrinsic defects and hydroxyl groups in a-SiO. J. Phys. C: Solid State Phys., 1984, 17, 221-225.

(61) Stegemann, B.; Gad, K. M.; Balamou, P.; Sixtensson, D.; Vössing, D.; Kasemann, M.; Angermann, H. Ultra-thin silicon oxide layers on crystalline silicon wafers: Comparison of advanced oxidation techniques with respect to chemically abrupt $\mathrm{SiO}_{2} / \mathrm{Si}$ interfaces with low defect densities. Appl. Surf. Sci. 2017, 395, 78-85.

(62) Sze, S. M.; Ng, Kwok K. Physics of Semiconductor Deivices, 3rd Edition, pp23, Chapter 1, 2007.

(63) Rohatgi, A.; Rounsaville, B.; Ok, Y.-W.; Tam, A. M.; Zimbardi, F.; Upadhyaya, A. D.; Tao, Y.; Madani, K.; Richter, A.; Benick, J.; Hermle, M. Fabrication and Modeling of High-Efficiency Front Junction N-Type Silicon Solar Cells With Tunnel Oxide Passivating Back Contact. IEEE J. Photovolt. 2017, 7, 1236-1243.

(64) Park, H.; Park, H.; Park, S. J.; Bae, S.; Kim, H.; Yang, J. W.; Hyun, J. Y.; Lee, C. H.; Shin, S. H.; Kang, Y.; Lee, H.-S.; Kim, D. Passivation quality control in poly-Si/SiO/c-Si passivated contact solar cells with $734 \mathrm{mV}$ implied open circuit voltage. Sol. Energy Mater. Sol. Cells 2019, 189, 21-26.

(65) Weiliang W.; J. B.; Xuguang J.; Zongtao L.; Lun C.; Binhui L.; Jingwei S.; Hui S. Dopant-free back contact silicon heterojunction solar cells employing transition metal oxide emitters. Phys. Status Solidi RRL 10, 2016, 9, 662-66.

(66) Stodolny, M. K.; Lenes, M.; Wu, Y.; Janssen, G. J. M.; Romijn, I. G.; Luchies, J. R. M.; Geerligs, L. J. n-Type polysilicon passivating contact for industrial bifacial n-type solar cells. Sol. Energy Mater. Sol. Cells 2016, 158, 24-28.

(67) Himpsel, F.J.; McFeely, F.R.; Ibrahimi, A.T. Yarmoff, J.A.; Hollinger, G. Microscopic structure of the Sion/Si interface. Phys. Rev. B 1988, 38, 6084-6096.

(68) Muller, D.A.; Sorsch, T.; Moccio, S.; Baumann, F.H.; Evans-Lutterodt K.; Timp, G. The electronic structure at the atomic scale of ultrathin gate oxides. Nature, 1999, 399, 758-761. 